\title{
Haitian Migration and Danced Identity in Eastern Cuba
}

\section{Citation}

Viddal, Grete. 2010. Haitian migration and danced identity in eastern Cuba. In Making Caribbean Dance: Continuity and Creativity in Island Cultures, ed. Susanna Sloat, 83-94. Gainesville, FL: University Press of Florida.

\section{Published Version}

doi:10.5744/florida/9780813034676.003.0007

\section{Permanent link}

http://nrs.harvard.edu/urn-3:HUL.InstRepos:10384888

\section{Terms of Use}

This article was downloaded from Harvard University's DASH repository, and is made available under the terms and conditions applicable to Other Posted Material, as set forth at http:// nrs.harvard.edu/urn-3:HUL.InstRepos:dash.current.terms-of-use\#LAA

\section{Share Your Story}

The Harvard community has made this article openly available.

Please share how this access benefits you. Submit a story.

Accessibility 


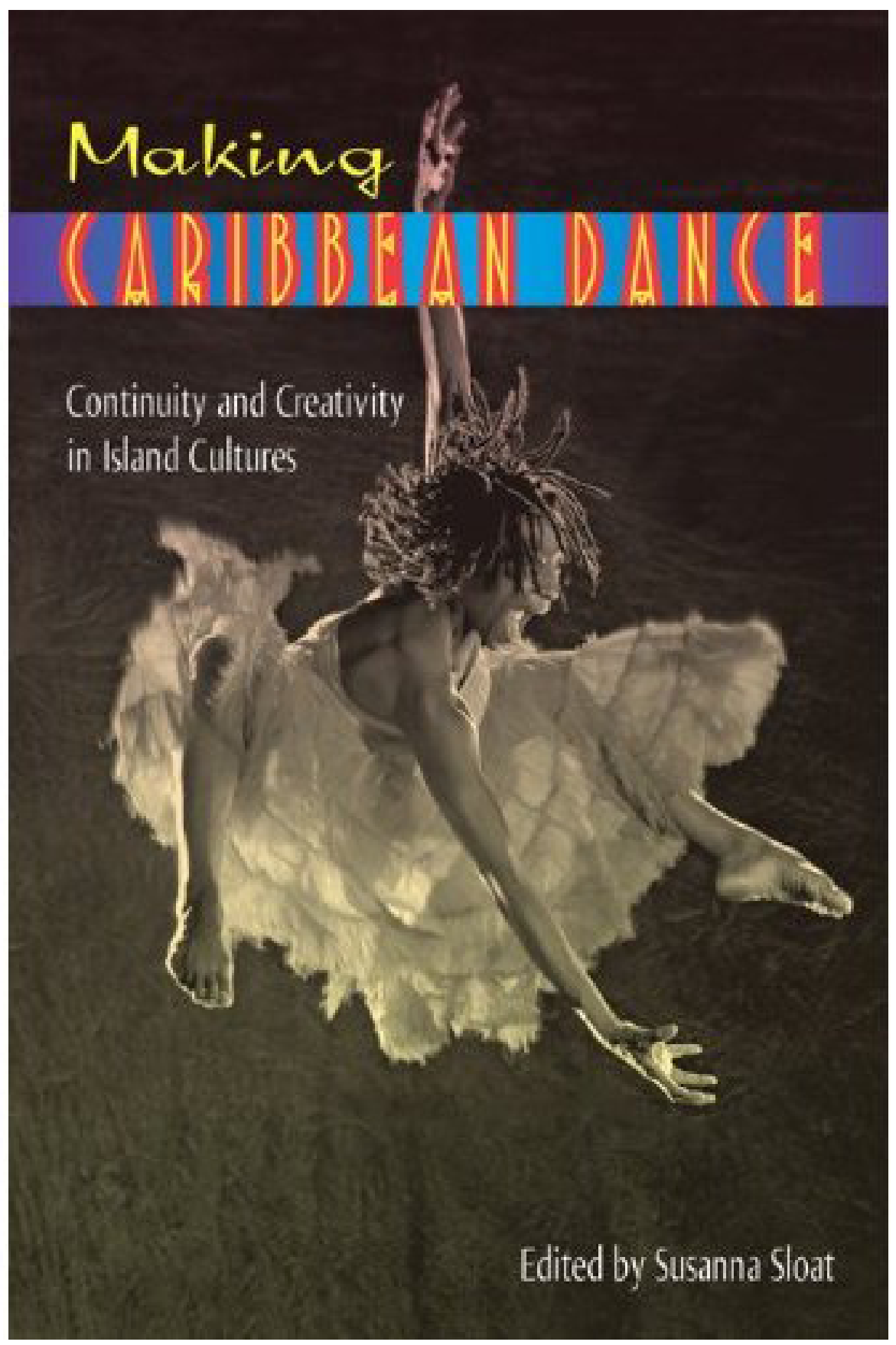




\section{7 \\ Haitian Migration and Danced Identity in Eastern Cuba}

GRETE VIDDAL

I arrive at Santiago de Cuba's Teatro Oriente to see a small crowd of locals and tourists waiting outside. We are here to see Ballet Folklórico Cutumba, one of eastern Cuba's premier folkloric dance troupes. Although the theater is run down and no longer has electricity or running water, its former elegance is apparent. As we enter, we see that lush but tattered velvet drapes flank the stage and ornate architectural details adorn the walls underneath faded and peeling paint. Light filters in through high windows. As the performance starts, women in elaborate ball gowns enter this dusty stage. They must hold up their voluminous skirts to keep yards of fabric from dragging on the floor. Men sport white topcoats with tails and matching white cravats. The costumes, modeled on eighteenth-century French court attire, may lead the audience to expect a re-enactment of an ancien régime ball.

Instead, the performance space fills with the driving rhythms of Africanstyle drums. This is the tumba francesa (French drum), a striking dance genre with roots in what is now Haiti that developed in eastern Cuba.

I had seen many different Havana styles portrayed in documentaries about Cuban dance. I'd read extensively on Cuban music and culture; however, I was completely unprepared for the exciting folkloric manifestations of Afro-Franco-Haitian-Cuban origin found in Cubas eastern provinces. In 1998, I traveled for the first time to Santiago de Cuba to participate in a study program hosted by Ballet Folklórico Cutumba, a group specializing in performing the dances of eastern Cuba. Cutumba's mission is to research, collect, conserve, and present these dances. 


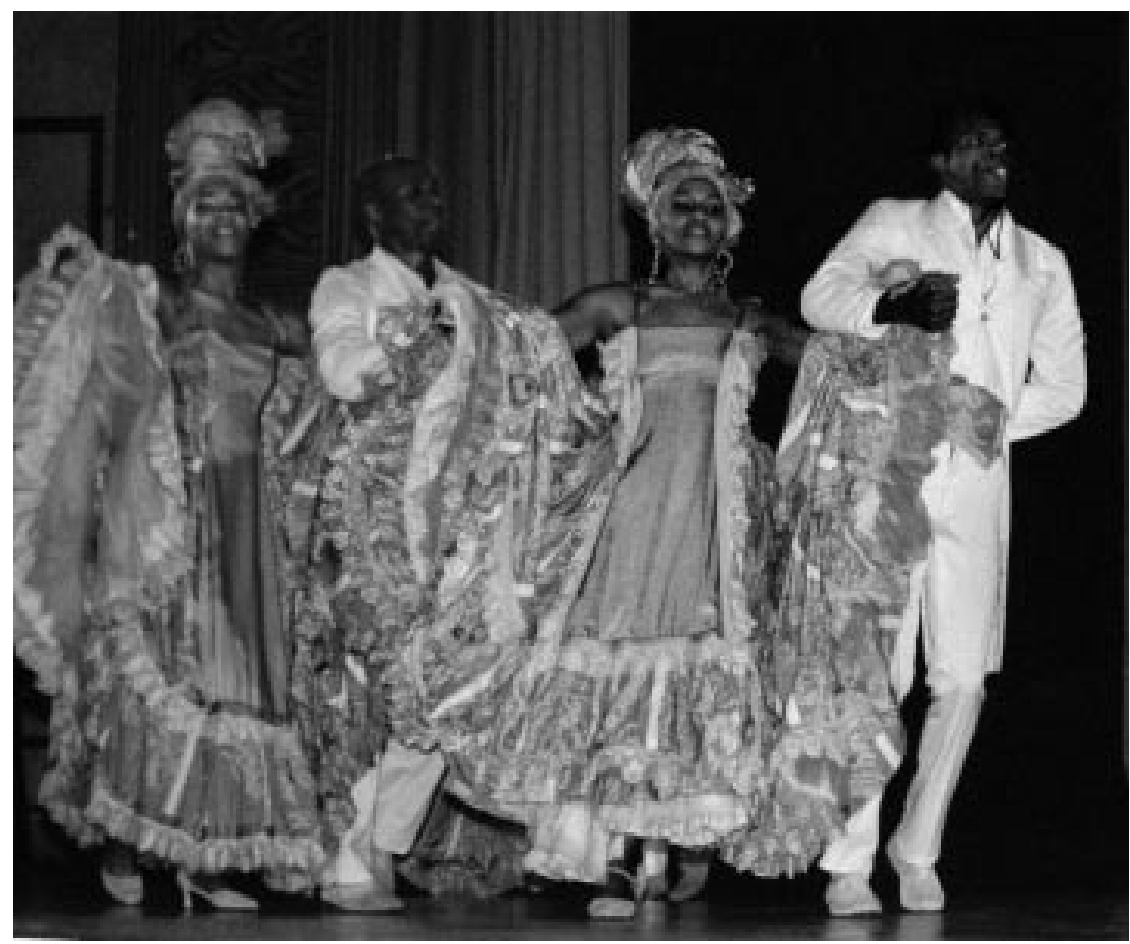

Figure 7.1. Cutumba performing Tumba Francesa. By Grete Viddal; used by permission.

Santiago de Cuba, the "capital of Oriente" - the island's eastern provinces-has been home to thousands of Haitian immigrants and retains a special culture that strongly differentiates it from Havana. Haitian Creole, referred to by speakers as patuá, is considered Cuba's "second language." It is estimated that more than 400,00o Cubans have at least "some familiarity" with Creole (Martínez Gordo 1989).

The eastern provinces of Cuba were host to two major waves of migration from Haiti, one during the time of the Haitian Revolution in the early nineteenth century, and another in the early twentieth century, when almost half a million Haitians were recruited as manual labor for eastern Cuba's expanding sugar industry. Both waves of migrants brought well-defined, and quite different, traditions of music and dance still practiced in Cuba today. 


\section{The Tumba Francesa (and Tajona)}

In eastern Cuba, the remaining tumba francesa societies and professional troupes such as Cutumba specialize in performing this intriguing dance genre. In Ballet Folklórico Cutumba's version, dancers in ornate costumes enter the stage promenading in stately rows. Tumba francesa is danced to the beat of a battery of African-style drums: the premier or maman (which improvises and solos), the segonde, the bulá, and the catá (an ideophonic drum, in this case a hollow log struck with two sticks). When Cutumba's musicians play, they fill the performance space with robust sound.

According to Ernesto Armiñan Linares, Cutumba's choreographer and an authority on regional performance, domestic slaves living in the households of the francophone plantocracy created the tumba francesa. They danced it wearing the cast-off finery of the masters. Later, free blacks of means and mulatto elites adopted these dances as well. Even before emancipation in Cuba (1886), tumba francesa clubs or societies were formed. Members held offices, such as that of presidente and presidenta. Public dances started with salutations to the organization's titleholders, then other visitors and local elders. Armiñan Linares explained to me that in later decades, heroes of Cuba's wars for independence were also ritually saluted by the societies. Today, two urban societies with their own buildings still exist, known as La Caridad in Santiago and La Pompadour in Guantánamo. A third group, the Tumba Francesa Bejuco, survives in an isolated mountain village in Holguin province.

The Santiago tumba francesa society and various professional troupes such as Cutumba also perform a dance called tajona (sometimes spelled tahona). According to Armiñan Linares, the tajona was a rural comparsa, or a festive procession of coffee plantation laborers taking advantage of a break in the work schedule to celebrate, parading along mountain roads after harvest time, singing and dancing. Before emancipation, the festivities of Holy Week gave slaves on mountain plantations an opportunity to visit relatives or friends on other estates. Armiñan Linares characterizes early tajona as a "dance of the field slaves," in contrast to tumba francesa's origins as a "dance of domestic slaves."

Musicologist Zobeyda Ramos Venereo (1997) hypothesizes that tajona has been influenced by and absorbed forms from other festive processional dances and music, particularly those associated with urban Santiago's carni- 
val clubs and saint's day festivals after post-emancipation population movements introduced rural dances to towns and cities. Antonio Pérez Martinez, currently the artistic director of Santiago's annual Festival del Caribe and a founder of Conjunto Folklórico Oriente, believes that tajona adopted steps and postures from the rumba of Havana and Matanzas in the early twentieth century, a period when cane cutters in search of work migrated from western to eastern Cuba. Concurrently, in 1912, the Cuban state banned a political party promoting civil rights for black Cubans, and the army was dispatched to the eastern provinces to prevent unrest. Some of these soldiers settled in the east and were also carriers of the rumba traditions (interview, December 15, 2008).

When Cutumba performs tajona, dancers enter in procession behind the mayor drapo, who carries a flag, and the bastonero, or baton carrier, who directs activities. Men and women execute steps reminiscent of the flirtatious pursuit and conquest patterns classic to Cuban rumba. The grand finale of Cutumba's tajona is a maypole dance. Dancers congregate around a tall pole festooned with ribbons and perform a complex series of interweaving steps around the pole to plait them. To unbraid the maypole, Cutumba dancers reverse their actions at double speed, jumping, twirling, and diving. According to troupe members, tajona processions are no longer active in the Cuban countryside; however, the tradition is maintained by tumba francesa societies and during Santiago's carnival, as well as by folkloric groups like Cutumba.

The city of Guantánamo, near but completely separate from the infamous U.S. military base, lies two hours drive east of Santiago de Cuba. Here, the tumba francesa society Santa Catalina de Riccis, locally known as Pompadour, gives weekly concerts. Demeanor is dignified and formal during masón, the dance that initiates Pompadour's performances of tumba francesa. Couples parade with curtseys and bows. Decorous and reserved dance steps are counterbalanced by dynamic percussive music. Next, the group presents the livelier yubá (also spelled jubá) and choreographies become more animated. As the music speeds up, couples begin to twirl and execute complex patterns.

To finish, Pompadour dances frenté, a competitive dance performed only by men. To begin, the men gather into a circle and fasten colored scarves to the arms, legs, and chest of a soloist. The player of the largest drum pulls his instrument into the circle, flips it sideways, sits on it, and begins to play 
quick riffs and sequences. Frenté is a friendly competition between dancer and musician, with displays of fancy footwork responding to challenging rhythms played by the lead drummer. Musicologist Olavo Alén explains in a Winter 1995 article in Ethnomusicology (56), "the premier player will always try to make his rhythmic improvisations so complex that the dancer will lose the rhythm or simply be unable to follow it; otherwise the dancer wins the challenge. When the duel between drummer and dancer is very close, the winner is determined by the applause of the spectators."

Watching tumba francesa performances made me curious. How did this dance genre arrive in Cuba? Had it really been performed in the eastern provinces for more than two centuries? Was this part of what made Oriente different from Havana? I began to learn about the colonial history of eastern Cuba, and the ways in which it was changed by events on a neighboring island.

\section{Saint-Domingue and Cuba}

Migrations resulting from the Haitian Revolution altered the cultural landscape of the Caribbean. In 1804, the colony of Saint-Domingue became Haiti, the western hemisphere's first independent black republic. SaintDomingue was France's most prosperous colony until a slave insurrection in 1791 spread across the country, eventually defeating even Napoleon's armies. As war engulfed Saint-Domingue in the years leading up to 1804, much of the French plantocracy fled, some with households that included domestic slaves. Free blacks and mulattos also joined the flood of refugees.

A large portion resettled in eastern Cuba, particularly in Santiago de Cuba and Guantánamo. By 1799, Calle Gallo, one of Santiago's main streets, had been renamed Grande Rue. By the end of the first decade of the nineteenth century, one of every four people in Santiago had come from what was now Haiti (Guanche 1983; Millet and Brea 1989; Bettelheim 2001; Duharte 2001).

Over the course of the next decades, former members of Saint-Domingue's colonial elite established coffee plantations (cafetales) in the hills and mountains surrounding Santiago. The planters of Saint-Domingue had experience growing coffee, a crop new to Cuba. The French taste for coffee, its spreading popularity in Europe, and the business acumen of the Saint-Domingue plantocracy combined to inaugurate a new economy in eastern Cuba. The 
franceses, as these immigrants were called, brought to the eastern provinces a repertoire of ballroom dances known as contredanse in French (eventually contradanza in Cuba) including quadrilles, the minuet, and cotillion. However, "The musicians who played for the Cuban contradanzas were black" (133) explains musicologist Ned Sublette in his 2004 book Cuba and Its Music. In Oriente, franceses negros took the European ballroom dances and remade them for their own pursuits, setting them to drum rhythms and creating their own tumba francesa. While the original ballroom dances of the white plantocracy faded from custom over the years, black franceses preserved their own versions of these dances.

Both enslaved and free blacks gathered for mutual aid and cultural expression in cabildos, social organizations active in Cuba since the early colonial period. Cabildos functioned as support networks. They also held dances and sponsored processions on holidays. The black franceses from Saint-Domingue began to form their own cabildos, which became known as tumba francesa societies, after the dances held there (Alén 1991).

In the decades following the arrival of the Saint-Domingue refugees, Franco-Haitian society in Cuba underwent a number of changes. With war in Europe between France and Spain in 1809 came an expulsion order, and French citizens living in Spanish colonies who had not pledged allegiance to the Spanish crown were ordered to leave. Many coffee plantation owners left for New Orleans, almost doubling that city's population (Sublette 2004). In the 1840s, hurricanes devastated eastern Cuba. Many cafetales were converted to sugar plantations or abandoned (Thomas 1998 [1971]). Cuba's first war of independence from Spain, the unsuccessful Ten Years War, lasted from 1868 to 1878 and further debilitated eastern Cuba's economy. As for the white franceses, Sublette describes their fate this way: "The coffee planters of Oriente, who had fallen on hard times already by 1840 , saw their industry destroyed; what remained of the French coffee bourgeoisie was ground down to a rural middle class" $(2004,245)$. While the ballroom dances of the eighteenth century faded from the salons of affluent whites, they have remained a tradition among black franceses for more than two centuries.

After the 1959 Cuban Revolution, the Cuban state took over the funding and supervision of all public cultural organizations, including tumba francesa societies. Today in Cuba, dance troupes are classified in three categories. Members of profesional groups are full-time state-salaried performers. Troupes officially categorized as aficionado or portador are provided with 
costumes and transportation by the government, but members maintain other jobs. Portadores are groups with family, neighborhood, or ethnic ties to a particular tradition, such as tumba francesa societies, carnival congas active since the early twentieth century, groups comprising descendants of Haitian, Jamaican, or Chinese laborers, or rural bands performing regional specialties such as chancleta or other country dances brought by Spanish immigrants.

In 2003 UNESCO, partnering with the Cuban government, provided funds for the renovation of Santiago's tumba francesa building under the auspices of the Convention for the Safeguarding of Intangible Cultural Heritage. Tumba francesa societies are potential tourist attractions and may help the eastern region capitalize on its distinctive cultural patrimony.

Santiago de Cuba is Cuba's second largest city, with a population of almost half a million. Although Havana dominates as the administrative hub and the governmental seat of power, where more than two million Habaneros enjoy the capital's hustle and bustle, cosmopolitan reputation, and erstwhile ties to Miami, a lively rivalry exists between these two cities. Santiagueros are proud to live in Cuba's most "Caribbean" city, pointing to their municipality's flavorful local culture, slow pace of life, animated carnival, neighborhood musical rivalries, and friendly population.

\section{Gagá (and Vodú)}

Gagá arrived in Cuba more than a century after tumba francesa. It was danced during the weeks leading up to Lent, when revelers paraded down roads and streets for miles, playing music, singing, displaying choreography and costumes, and vying to outdo other bands. This tradition came to Cuba with the Haitian labor migrants of the early 190os. Specific sociopolitical conditions brought gagá to Cuba.

The United States entered the Cuban War for Independence in February 1898, fighting against Spain in what is known in U.S. history books as the Spanish American War. The war ended in Cuba's liberation from Spain in August of the same year, but the new country was independent in name only. President McKinley installed a military government and created the Platt Amendment, effectively making Cuba a U.S. dependency. By 1905, only 25 percent of land in Cuba was still owned by Cubans (Helg 1995); most of the rest now belonged to U.S. corporations and speculators. Expanding Cuba's 
sugar industry became a top priority, and this required intensive, inexpensive manual labor.

In the years following the war, former Cuban liberation fighters rallied for their rights with strikes and insurrections. The United Fruit Company, with extensive holdings in eastern Cuba, needed a servile workforce to toil on its growing plantations. According to Thomas, "in late 1912, after the Negro revolt, the United Fruit Company asked if they could bring in 1,400 Haitians to work on their plantations in Oriente. . . . In succeeding years, a torrent of black labourers came, Haitians and Jamaicans" (1998 [1971], 524).

Meanwhile, in Haiti, the United States responded to a period of internal political turmoil by invading the country in 1915, ostensibly to promote peace in the region, but in reality eager to protect U.S. investments and business interests. The United States Marines occupied Haiti for almost two decades, carrying out policies that caused trauma and displacement of the peasant population. Wages on Cuban sugar and fruit plantations, although meager, were higher than in Haiti. Between 1913 and 1931, some scholars believe that as many as 500,000 Haitians (and 75,000 Jamaicans) entered Cuba (James, Millet, and Alarcón 1992). Many of these migrants, called braceros (referring to "strong arms"), went to work on plantations in the eastern provinces.

The arrival of more than half a million Antillean immigrants during the first decades of the twentieth century profoundly changed eastern Cuba's cultural mix. Many Haitians never returned to Haiti and settled in Oriente, both rurally and in Santiago, Guantánamo, and Camagüey (Guanche and Moreno 1988; McLeod 200o). They brought with them, and in many cases maintained, their own traditions, religious beliefs, and music, a fact that has received relatively little notice in official narratives about Cuban cultural history.

Investigation into eastern Cuba's distinctive St. Dominguan-Haitian heritage raises many questions. Conversations with the Cuban ethnomusicologist Olavo Alén highlighted the possibility that tumba francesa music and dance may have changed as former slaves from the plantations moved to towns and cities. The role of the descendants of free St. Dominguans of color in the establishment of the urban tumba francesa societies needs further study. Furthermore, when the second wave migrants of the early 1900 found more than century-old populations from Saint-Domingue in eastern Cuba, did the new arrivals identify with the earlier group's culture? 


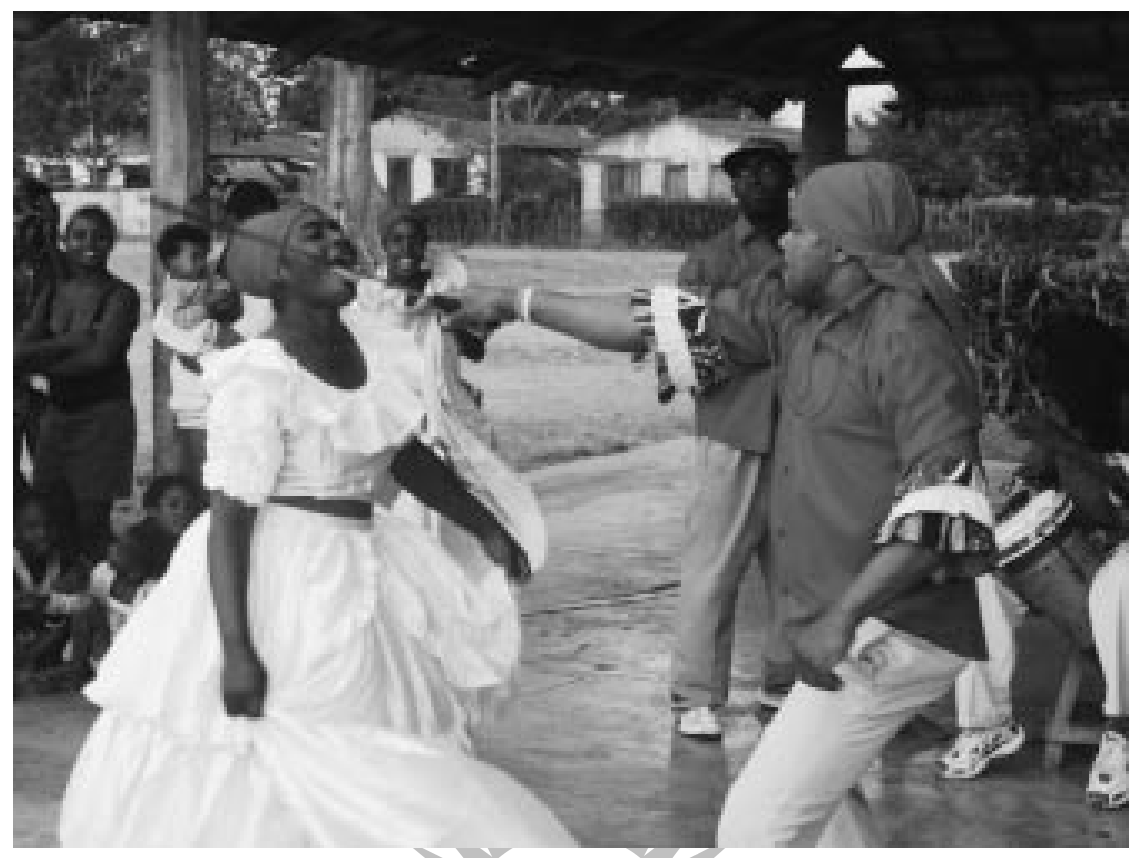

Figure 7.2. Gagá performance by Grupo Folklórico Thomson. By Grete Viddal; used by permission.

Could they "dance the same dances," or were there clashes? At present, the tumba francesa societies identify their dances as "francés," but other folkloric troupes describe the same repertoire as "franco-haitiano."

Today Ballet Folklórico Cutumba's performance of gagá never fails to elicit gasps and cheers from the audience. After the musicians have settled onstage, scouts enter and theatrically scrutinize the audience and theater. When the area is declared safe, the flag carriers, baton twirlers, and a dancer with a giant, colorful, beribboned headpiece called the roi diable follow the scouts. The references to defense and protection within festivity and celebration are unmistakable. Traditionally, gagá bands are competitive. Choreography typically includes theatrical feats of bravery and skill, such as twirling machetes, throwing and catching torches, leaping, tumbling, walking across broken bottles, and deftly lifting tables laden with glasses of water and vases of flowers. Alexis Alarcón (1988) theorizes that gagá spectacles implicitly carry historically important cultural messages. They impress upon spectators that Haitians and their descendants, the poorest and most vulnerable migrant workers of the early twentieth century, are capable of dramatic feats 
of daring and skill, and in this way craft a protective stereotype for Haitians in Cuban society.

Known as rara in Haiti, this art form can be subversive. In her 2002 book Rara!, Elizabeth McAlister collected rara songs that comment on local and national issues or poke fun at elites. Many rara bands in contemporary Haiti are associated with Vodou congregations and traditional religious leadership. Whether gagá in Cuba once played a role similar to that of rara in Haiti is an intriguing question my research seeks to answer.

The repertoire of Haitiano-Cubano folkloric performance includes choreographies inspired by the religious dances of Vodou, typically spelled Vodú in Cuba. Haitian spiritual practices have been maintained by descendants of Haitian migrants in Cuba. Although Vodú is most typically practiced in the countryside, Vodú believers are in contact through networks across the whole island. Well-known Vodú priests and priestesses cross Cuba to take part in ceremonies on saint's days or attend state-sponsored festivals. Several also direct folkloric troupes and leave their towns on trucks and buses to perform in Santiago's Festival del Caribe, Guantánamo's carnival, or Ciego de Avila's spring dance festival. During an excursion to the village of Thomson in Santiago province, I found a hamlet with a six-student school, one tiny bodega, and a twenty-five-member Haitian folkloric dance troupe, complete with musicians, instruments, costumes, flags, banners, and rehearsal schedules.

Such local groups as well as professional ones like Cutumba perform dances from Vodú religious rites, adapted for the stage, including ibó, nagó, and yanvalú. (Some of these names reflect African ethnic groups brought to Haiti as slaves: the Ibo from what is now southeastern Nigeria, the Nago also from Nigeria and today known as Yoruba). Secular dances include merengue haitiano, a couple dance for festive occasions, and congo layé, with its mimed flirtatious pursuits between male and female dancers (not to be confused with carnival congas, in which dancers wind their way through the streets of Santiago de Cuba, shuffling conga style with a step that emphasizes the hip, and sometimes breaking into kicks, wiggles, and more complex improvisations as they follow carnival musicians).

The Cuban state is highly centralized, with many academies, institutes, and organizations headquartered in Havana. The music, arts, folklore, and religious traditions of the region surrounding Havana have been privileged in the distribution of resources, and in many cases have become synony- 
mous with Cuban culture in general. But Havana's story is not Cuba's story. Scholarship on Cuban religious and performance culture has focused on Havana and its surrounds, equating the island's capital with its core, but lively customs set Oriente apart, contributing to the creation of a distinctive regional identity.

While some Cubans of Haitian descent hide their heritage or have assimilated, the pride-building efforts of specialized performance troupes and the emergence of regional folklore festivals sponsored by local cultural institutes are beginning to bear fruit. During an annual folk-dance festival in Violeta in Ciego de Avila province in April 2009, I found that five of the seven groups specialized in Haitiano-Cubano dances. The festival even featured an open-to-the-public Vodú ritual hosted by a local family of Haitian descent. Cubans of varied ethnic heritage across the skin color spectrum attended, enthusiastically imitated dance steps, and joined in the call and response songs. On the final evening of the festival, youthful spectators ignored a DJ spinning reggaetón hits to cluster around a performance group of rural villagers of Haitian descent performing gagá and Vodú dances. In eastern Cuba, members of a historically marginalized and denigrated population are using folkloric performance to challenge marginalization, build cultural capital, and cultivate regional pride.

Tumba francesa fused elite French court dances with African music. Gagá tells the story of Cuba's understudied and unheralded Haitian heritage. Dance can function as a kind of "embodied history," enriching and extending our understanding of migration and identity. 